
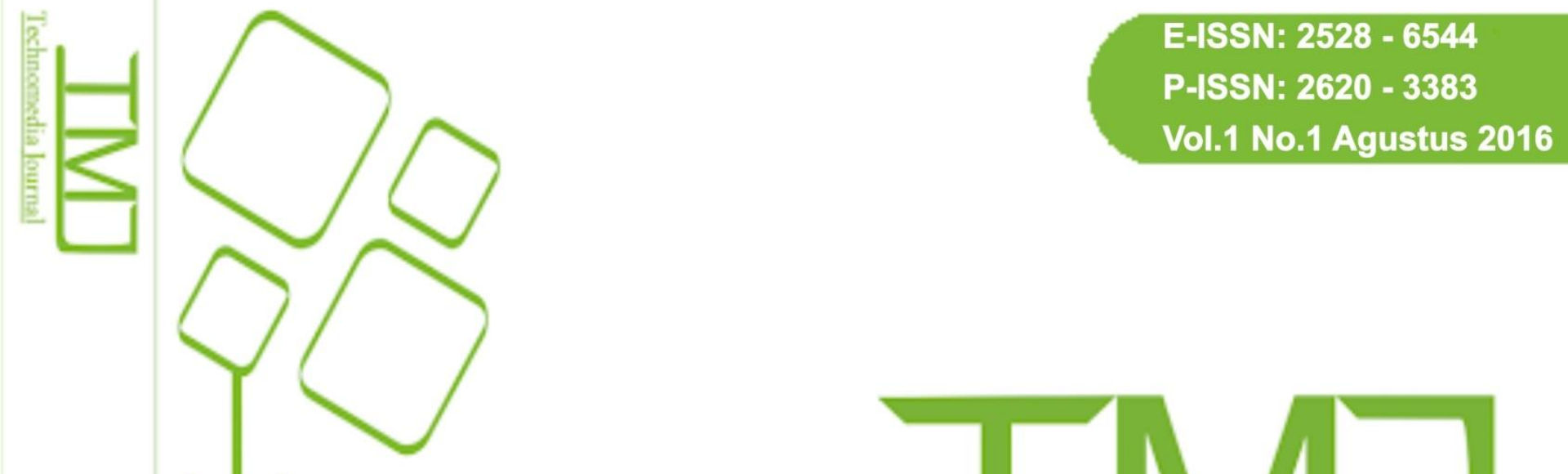

Technomedia Journal

iLearning Journal Center (iJC)

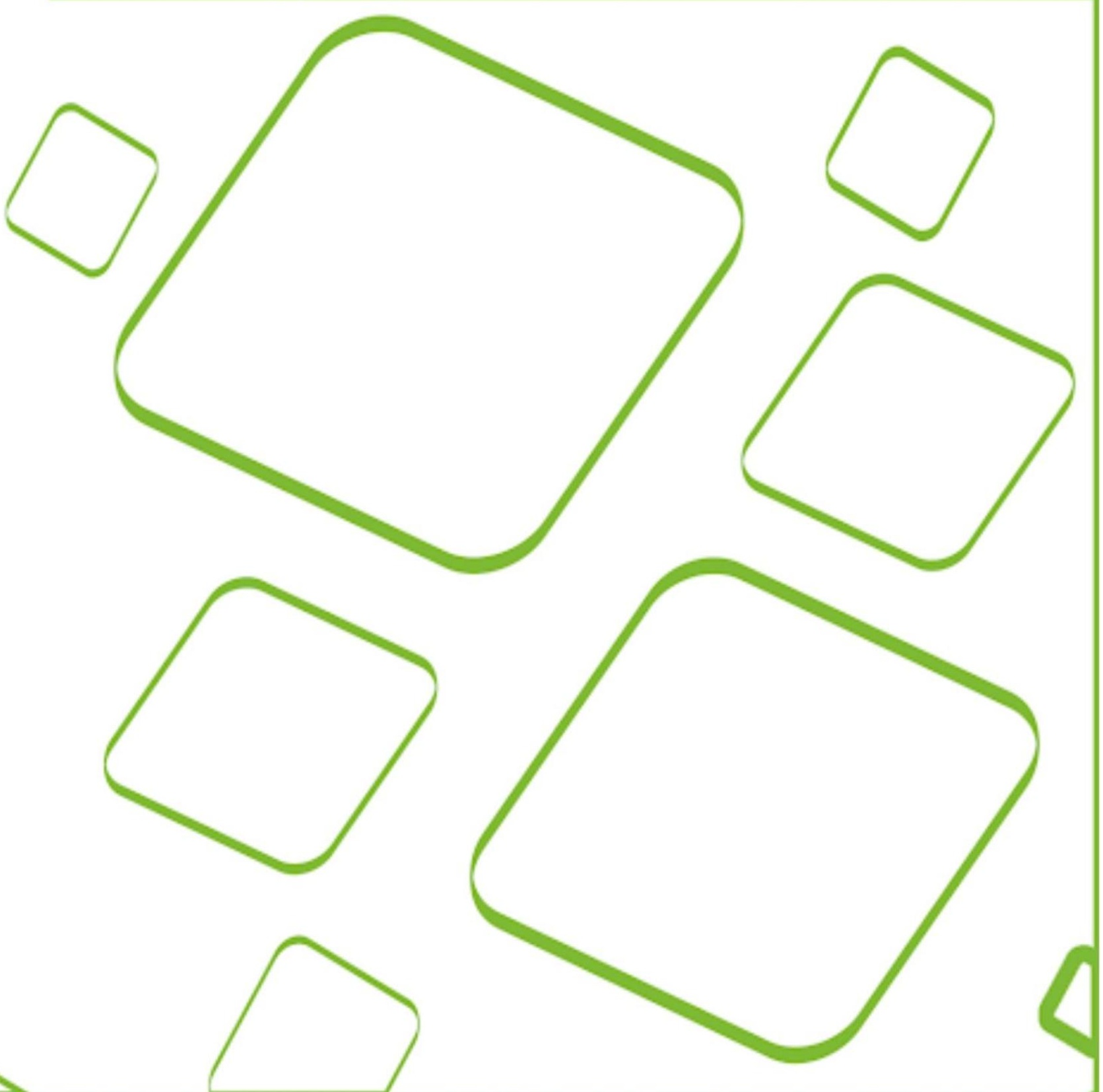


Technomedia Journal adalah jurnal elektronik ilmiah yang diterbitkan oleh iJC (iLearning Journal Center). Technomedia Journal terbit tiga kali dalam satu tahun Februari, Juni, dan Oktober yang berisi artikel hasil penelitian dalam bidang Sistem Informasi dan Teknologi Informatika.

Ketua Redaksi :

Ir. Untung Rahardja.,M.T.I

Sekretaris Redaksi :

Indri Handayani, S.Kom., M.T.I

Mitra Bestari :

Prof. Ir. Joko Lianto Buliali, M.Sc.,Ph.D

Prof. Dr.rer.nat. Achmad Benny Mutiara, SSi, SKom

Prof. Dr. Moedjiono. MSc

Dr. Winarno

Dr. Harco Lesly

Panca Oktavia Hadi Putra, Bsc., M.Sc.,

Henderi, M.Kom

Dr. Ir. I. Joko Dewanto, MM

Dr. Ir. Sudatyono, S.Pd., M.Pd

\section{Editor/ Layout : \\ Maulana Sani \\ Yuli Widiastuti}

\section{Bendahara:}

Eka Purnama Harahap, S.Kom

\section{Alamat Redaksi :}

Jl. Jendral Sudirman No 40, Cikokol - Tangerang Tel / fax : (021)5529692

Email: ijc@ raharjagroups.info atau ijc@ raharja.info 


\section{Dewan Redaksi}

Puji dan syukur kehadirat Allah SWT atas karunia dan lindunganNya sehingga TMJ terbitan Vulume 1 Nomor 1 Edisi Oktober 2016 dapat diterbitkan tepat waktu.

Penerbitan jurnal ini dimaksudkan sebagai media informasi ilmiah dibidang ilmu komputer yang diharapkan dapat membantu para dosen dan mahasiswa dalam menginformasikan hasil penelitian dan kajian ilmiah lainnya kepada berbagai komunitas ilmiah diseluruh Indonesia.

Penerbitan jurnal Volume 1 Nomor 1 Edisi Oktober 2016 berisikan 10 artikel yang mencakup bidang Ilmu Komputer, Teknologi Informasi, Sistem Informasi, walaupun tidak seluruhnya merupakan hasil penelitian diharapkan dapat bermanfaat bagi pembacanya. Puji syukur kehadirat Allah SWT karena 10 artikel adalah dari STMIK dan AMIK Raharja.

Jurnal ini diterbitkan dengan memuat artikel Fitur Form Emailer Dalam Memaksimalkan Penggunaan Rinfo Form Pada Perguruan Tinggi, Implementasi Fgr (First Generation Resources) Dengan Menggunakan Mailchimp Sebagai Sarana Informasi Di Perguruan Tinggi, Optimalisasi Penerapan Rooster Berbasis Osticket Untuk Meningkatkan Mutu Pelayanan, Penerapan Rinfosheet Sebagai Media Penunjang Pembuatan Laporan Untuk Mahasiswa, Penerapan Rinfosheet Sebagai Media Penunjang Pembuatan Laporan Untuk Mahasiswa, Optimalisasi Viewboard Rhjfox Berbasis Bootstrap Sebagai Sistem Penunjang Keputusan, Penerapan Viewboard Go+ Berbasis Yii Sebagai Media Monitoring Pembayaran Mahasiswa, Pemanfaatan Rinfo Form Sebagai Media Pembuatan Kuesioner Dalam Proses Pengumpulan Data Pada Perguruan Tinggi, Pemanfaatan Google Scholar Dan Citation Dalam Memenuhi Kebutuhan Pembuatan Skripsi Mahasiswa Pada Perguruan Tinggi, Penerapan Mata Uang Armo (Airzone-Mall Money) Pada Marketplace Airzone-Mall Sebagai Inovasi Pembelajaran Internet Dan E-Commerce, Media Audio Visual Menggunakan Videoscribe Sebagai Penyajian Informasi Pembelajaran Pada Kelas Sistem Operasi.

Tidak lupa pula pada kesempatan ini kami mengundang para pembaca untuk mengirimkan naskah hasil penelitian kepada kami. Dan tidak lupa pula kami mengucapkan banyak terimakasih kepada semua pihak yang telah membantu penerbitan jurnal ini.

Tangerang, 31 Oktober 2016

Redaksi 


\section{Daftar Isi}

1. FITUR FORM EMAILER DALAM MEMAKSIMALKAN PENGGUNAAN RINFO FORM PADA PERGURUAN

TINGGI......................

2. IMPLEMENTASI FGR (FIRST GENERATION RESOURCES) DENGAN MENGGUNAKAN MAILCHIMP SEBAGAI SARANA INFORMASI DI PERGURUAN TINGGI. Qurotul Aini, Indri Handayani, Nuril Huda

3. OPTIMALISASI PENERAPAN ROOSTER BERBASIS OSTICKET UNTUK MENINGKATKAN MUTU PELAYANAN

4. PENERAPAN RINFOSHEET SEBAGAI MEDIA PENUNJANG PEMBUATAN LAPORAN UNTUK MAHASISWA

Khanna Tiara Erlita Rasdiana, Nursam Somantri

5. OPTIMALISASI VIEWBOARD RHJFOX BERBASIS BOOTSTRAP SEBAGAI SISTEM PENUNJANG KEPUTUSAN...... 50-64 Untung Rahardja, Khanna Tiara, Maya Ima Erviani

6. PENERAPAN VIEWBOARD GO+ BERBASIS YII SEBAGAI MEDIA MONITORING PEMBAYARAN MAHASISWA Khanna Tiara, Tuti Nurhaeni, Ika amalia

7. PEMANFAATAN RINFO FORM SEBAGAI MEDIA PEMBUATAN KUESIONER DALAM PROSES PENGUMPULAN DATA PADA PERGURUAN TINGGI Erlita Rasdiana, Fadil Nur Muhamad, Ridwan Kurniaji

8. PEMANFAATAN GOOGLE SCHOLAR DAN CITATION DALAM MEMENUHI KEBUTUHAN PEMBUATAN SKRIPSI MAHASISWA PADA PERGURUAN TINGGI...................... Untung Rahardja, Khanna Tiara, Iis Ariska Rosalinda

9. PENERAPAN MATA UANG ARMO (AIRZONE-MALL MONEY) PADA MARKETPLACE AIRZONE-MALL SEBAGAI INOVASI PEMBELAJARAN INTERNET DAN E-COMMERCE. Qurotul Aini, Untung Rahardja, Dita Lintang Nurani

10. MEDIA AUDIO VISUAL MENGGUNAKAN VIDEOSCRIBE SEBAGAI PENYAJIAN INFORMASI PEMBELAJARAN PADA KELAS SISTEM OPERASI 


\title{
Optimalisasi Viewboard Rhjfox Berbasis Bootstrap Sebagai Sistem Penunjang Keputusan
}

\author{
Untung Rahardja 1 \\ Khanna Tiara ${ }^{2}$ \\ Maya Ima Erviani ${ }^{3}$ \\ Jl. Jend. Sudirman No. 40, Modern Cikokol, Tangerang ${ }^{1,2,3}$ \\ E-mail: $\underline{\text { untung@raharja.info }}{ }^{1}, \underline{\text { khanna.tiara@ raharja.info }}{ }^{2}$, maya.ima@ raharja.info ${ }^{3}$
}

\begin{abstract}
ABSTRAK
Seiring dengan pesatnya perkembangan di dunia telekomunikasi yang ditandai dengan era digital, khususnya di bidang Teknologi Informasi dan Komunikasi. Raharja Fox atau biasa juga disebut dengan RhjFox, merupakan sebuah forum online resmi yang dibuat untuk Perguruan Tinggi Raharja sebagai tempat untuk berdiskusi dan bertukar pikiran dalam hal hobi, pendapat, atau aktifitas lainnya. RhjFox juga bertujuan untuk meningkatkan wawasan dan pengetahuan Pribadi Raharja, untuk mengembangkan kreatifitas pada Pribadi Raharja, untuk menyediakan informasi mengenai Perguruan Tinggi Raharja, serta untuk menjadi tempat diskusi dan bertukar pendapat atau pikiran. Keistimewaan RhjFox adalah dapat menyajikan informasi yang berhubungan dengan Perguruan Tinggi Raharja maupun informasi dari pengetahuan luar Perguruan Tinggi Raharja. viewboard RhjFox adalah sebuah Tampilan yang menggambarkan aktifitas didalam RhjFox yang datanya bersumber dari database RhjFox untuk para member RhjFox seperti Pribadi Raharja, Staff, dan Dosen. Dengan adanya viewboard RhjFox dapat bertujuan untuk menginformasikan mengenai datadata yang ada di database RhjFox sehingga menjadi sebuah penunjang keputusan yang nantinya akan menampilkan informasi akurat dan terkini yang berkaitan dengan perihal RhjFox. Database merupakan persyaratan dalam membuat sebuah Sistem Penunjang Keputusan berbasis komputer. Sistem penunjang keputusan ini membantu dan memberikan alternatif untuk pihak manajerial, dan kepada khalayak ramai umumnya. Hal ini berguna untuk memudahkan pengambil keputusan yang terkait dengan masalah mengolah data yang terdapat pada RhjFox menjadi sebuah viewboard.
\end{abstract}

Kata kunci : RhjFox, Viewboard, Penunjang Keputusan

\begin{abstract}
Along with the rapid development of telecommunications in the world characterized by the digital age, particularly in the field of information and communication technology. Raharja Fox or also known as RhjFox, is an official online forum created forRaharja College as a place to discuss and exchange ideas in terms of hobbies, opinions, or other activities. RhjFox also aims to enhance personal knowledge and insightRaharja, to develop creativity in Personal Raharja, to provide information about College Raharja, as well as to be a place of discussion and exchange opinions or thoughts. RhjFox privilege is able to present information related to College Raharja nor information from knowledge outside College Raharja. viewboard RhjFox is a Display which describes activities in RhjFox whose data is sourced from the database RhjFox tothe member RhjFox as Personal Raharja, Staff, and professors. With the viewboard RhjFox can aim to inform about the existing data in the database of RhjFox so that it becomes an ancillary decision that later will display current and accurate information relating to the subject RhjFox. The database is a requirement in making a computer-based Decision Support Systems. This decision support system to assist and provide an alternative to the managerial, and party to the general audience. It is useful to make it easier for decision makers associated with processing the data contained on a RhjFox into a viewboard.
\end{abstract}

50 | Untung, Khanna, Maya - Analisa Viewboard RhjFox... 
Keywords: RhjFox, Viewboard, Decision Support

\section{PENDAHULUAN}

Seiring dengan semakin berkembangnya dunia teknologi dan informasi, lahirlah website yang merupakan suatu media informasi yang menawarkan berbagai kemudahan dalam menyajikan informasi, lebih dari itu website juga menjadi wadah diskusi yang sering di gunakan oleh banyak orang khususnya mahasiswa. Dan di Perguruan Tinggi Raharja juga terdapat sebuah website forum resmi yang telah dibuat yaitu RhjFox. Sehingga tercipta website dimana website ini ialah sekumpulan untuk berbagi informasi yang sangat berguna untuk orang banyak, informasi begitu dibutuhkan oleh orang banyak pada zaman ini.

Website disebut world wide web untuk simpan kedalam file yang berbeda bagi halaman web yang bisa akses secara grafis. Website ialah sekumpulan halaman yang bisa menampilkan suatu informasi data teks, gambar diam dan bergerak, animasi, suara, video, ataupun yang sifatnya statis dan dinamis. Perkembangan forum ini tidak terlepas dari pengaruh perkembangan zaman. Kemajuan teknologi untuk forum dikemas secara efisien dan mudah.

Perguruan Tinggi Raharja sebagai suatu institusi bagi civitas yang besar punya website forum untuk berdiskusi yang dinamai RhjFox. Forum ini bisa menjadi wadah untuk tempat berdiskusi dan juga bertukar pikiran, pendapat, ataupun mencari informasi tentang pengumuman di kampus Perguruan Tinggi Raharja antar sesama Pribadi Raharja.

RhjFox merupakan forum online yang dijadikan sebagai tempat diskusi untuk menjebatani kesamaan hobi, aktivitas, pendapat ataupun keinginan antar mahasiswa, dosen dan staff. Sistem RhjFox ini berbasis PHPBB. Sama halnya seperti Social Network yang sedang ramai- ramainya di dunia maya. dimana didalam forum RhjFox tersebut terbagi menjadi sub-sub dari forum Raharja Fox, lebih jelasnya didalam forum RhjFox tersebut ada pembagian kategori yang dibuat untuk memudahkan penggunanya dalam berinteraksi. atau bisa diartikan sebagai tempat untuk berinteraksi bagi para anggotanya dimana dengan adanya kategori pembahasan di tiap-tiap forum RhjFox bisa mempermudah para anggota dalam mencari sebuah informasi. Forum RhjFox memiliki cara berkomunikasi Hingga saat ini, penggunanya dibatasi kepada pemegang akun email Rinfo (misalnya@raharja.info). Hal itu dikarenakan RhjFox lebih mengutamakan interaksi antara civitas akademika Perguruan Tinggi Raharja.

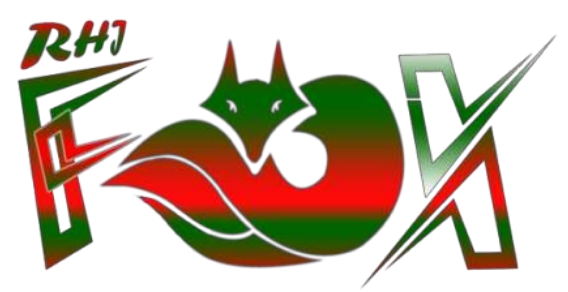

Sumber: http://rhifox.com/

Gambar 1. RhjFox 


\section{PERMASALAHAN}

RhjFox telah menjadi salah satu media interaksi online dalam ekosistem pendidikan dan pengajaran Perguruan Tinggi Raharja yang cukup sukses. Hal tersebut dapat dilihat dari banyaknya jumlah pengguna yang telah mendaftarkan dirinya, beragamnya kategori yang memudahkan para pengguna untuk berinteraksi kepada sebuah topik yang cukup spesifik, dan juga banyaknya topik dan postingan yang telah dibuat oleh para penggunanya. Namun, semua data itu masih terlalu mentah untuk diolah. Karena data-data tersebut hanya berupa angka semata yang tidak memberikan informasi yang cukup banyak. Dengan banyaknya data namun kurangnya informasi, bisa menyebabkan kerugian yang cukup besar bagi pihak manajerial karena data tersebut belum bisa dijadikan acuan untuk mengambil sebuah keputusan. Informasi yang diberikan oleh sistem pun tidak begitu membantu. Karena pada dasarnya, PHPBB hanya sebuah platform diskusi yang memberikan fitur penuh diskusi, bukan statistik.

PHPBB tidak memberikan fitur viewboard yang diharapkan dapat memberikan informasi yang dapat membantu pihak manajerial dalam pengambilan keputusan berdasarkan aktifitas yang ada di RhjFox. Misalnya, mahasiswa jurusan apakah yang terbanyak mendaftar di RhjFox, atau siapakah pengguna yang paling aktif di RhjFox, dan lain sebagainya.

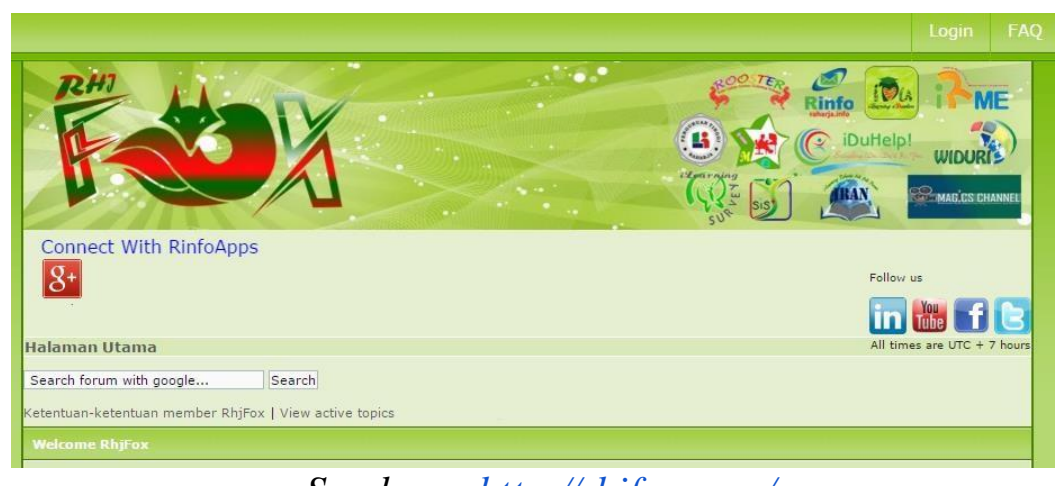

Sumber : http://rhifox.com/

Gambar 2. Tampilan RhjFox Tanpa Viewboard RhjFox

Hal ini menjadi dasar pemikiran rumusan masalah dalam penelitian ini adalah bagaimana mengolah data yang terdapat pada RhjFox menjadi sebuah viewboard yang menampilkan informasi akurat dan terkini yang berkaitan dengan perihal RhjFox, yang nantinya diharapkan dapat menjadi informasi penunjang pengambil keputusan untuk pihak manajerial, dan kepada khalayak ramai umumnya.

Berdasarkan rumusan masalah tersebut, maka tujuan peneliti adalah menciptakan sebuah viewboard yang dapat menginformasikan atau memetakan data yang ada di basis data RhjFox dengan baik dan mudah dimengerti. Juga menggunakan Bootstrap sebagai fondasi desainnya karena bersifat responsif, yang artinya dapat tampil dengan baik di berbagai browser ataupun platform akses.

\section{LITERATURE REVIEW}

Literature review adalah bahan yang tertulis berupa buku, jurnal yang membahas tentang topik yang hendak diteliti ([Menurut Hermawan 2009:45]). Banyak penelitian yang sebelumnya 
dilakukan mengenai viewboard RhjFox. Dalam upaya viewboard RhjFox ini perlu dilakukan studi pustaka sebagai salah satu dari penerapan metode penelitian yang akan dilakukan. Berikut ini adalah 10 penelitian yang telah dilakukan dan memiliki kolerasi yang searah dengan penelitian yang akan dibahas dalam Jurnal ini diantaranya :

1. Penelitian yang dilakukan oleh Lusyani Sunary, Radiyanto, Erna Susanti (2013) penelitian ini berjudul "Enriching Company Profile Sebagai Penunjang Media Informasi Dan Promosi Pada Perguruan Tinggi Raharja”. Pada penelitian ini, penulis bertujuan untuk Untuk mengembangkan media informasi dan promosi berupa buku company profile yang efektif dan komunikatif yaitu dengan cara memperbarui dan mengembangkan design dan isi dari informasi yang akan disampaikan dan disesuaikan dengan kemajuan sistem dan fasilitas yang ada pada Perguruan Tinggi Raharja sebagai sarana media penyampaian informasi dan promosi yang mampu mengemas seluruh aset yang dimiliki oleh Perguruan Tinggi Raharja agar mudah diterima oleh masyarakat.

2. Penelitian yang dilakukan oleh Septiana Wulandari, Dian Kurniasari, Widiarti (2014) penelitian yang di lakukakan ini berjudul "Pendugaan Galat Baku Nilai Tengah Menggunakan Metode Resampling Jackknife dan Bootstrap Nonparametric dengan Software R 2.15.0”. Hal yang melatarbelakangi penelitian ini adalah Metode Jackknife dan Bootstrap merupakan metode berbasis resampling. Kedua metode ini biasa digunakan untuk inferensia statistic, yaitu pada pendugaan parameter dengan sebaran awal yang tidak diketahui. Metode Jackknife dan Boostrap merupakan metode yang tidak didasarkan pada pemenuhan asumsi tertentu, sehingga metode ini dapat diterapkan pada seluruh data kuantitatif. Secara teori dapat dibuktikan bahwa metode Jackknife merupakan penduga yang baik untuk data asal. Namun berdasarkan kreteria Kuadrat Tengah Galat (KTG), metode Bootstrap lebih tepat digunakan karena menghasilkan nilai KTG yang lebih kecil dibanding metode jackknife.

3. Penelitian yang dilakukan oleh Akhmad Fauzy (2003) penelitian ini berjudul "Interval Selisih Rata-Rata Dengan Metode Bootstrap Persentil". Pada penelitian ini penulis hanya membahas metode yang lebih baik di dalam menduga interval selisih rata-rata pada sampel kecil adalah metode bootstrap persentil. Metode tersebut menghasilkan lebar interval yang lebih sempit apabila dibandingkan dengan metode tradisional.

4. Penelitian yang dilakukan oleh Hendro Prasetyo, Kuntoro, Windhu Purnomo, Soenarnatalina, Merry Adriani, Bambang Wijanarko (2014) penelitian ini berjudul "Penerapan Clustering Bootstrap dengan Metode K-Means". Pada penelitian ini penulis membahas tentang Analisis Cluster adalah sebuah proses untuk mengelompokkan satu set objek berdasarkan data yang telah similar certain karakteristik. K-Means adalah metode analisis cluster yang dimulai dengan menentukan jumlah cluster yang diinginkan. Bootstrap adalah teknik sampling dengan penggantian dari sampel asli. Bootstrap digunakan untuk memperkirakan parameter berdasarkan data minimal menggunakan komputer.

5. Penelitian yang dilakukan oleh Ilamsyah, Asep Awaludi, Nurwendah (2015) penelitian ini berjudul "Implementasi Bootstrap Pada Sistem Informasi Perpustakaan Untuk Meningkatkan Pelayanan Mahasiswa Pada Perguruan Tinggi Raharja”. Pada penelitian ini penulis membuat suatu Sistem informasi perpustakaan ini dibangun 
menggunakan teknologi berbasis web dengan bahasa pemgrograman PHP dan menggunakan XAMPP sebagai web servernya. Tujuan dibangunnya sistem informasi ini adalah untuk mengatasi masalah dalam kesulitan pencarian data buku dan dokumentasi adminsitrasi perpustakaan. Dengan penggunaan bootstrap diharapkan dapat meningkatkan kenyamanan bagi pengguna, karena dengan tekhnologi bootstrap memungkinkan web yang dibangun dapat di tampilkan dengan lebih baik pada perangkat seperti smartphone, tablet dan lainnya. Disamping ini keuntungan dari penggunaan sistem berbasis web ini dapat meningkatkan efektifitas pelayanan administrasi pada perpustakaan karena pengunjug dapat dengan mudah mendapatkan informasi buku yang akan dipinjam. Disamping itu bagi pihak perguruan tinggi Raharja, sistem ini dapat meningkatkan efisiensi karena mengurangi penggunaan kertas sebagai media dokumentasi peminjaman dan pengembalian.

6. Penelitian yang dilakukan oleh Untung Rahardja, Yessi Frecilia, Noval Jindan (2015) penelitian ini berjudul "Penerapan Forum RhjFox Menggunakan Metode PHPBB Sebagai Media Pembelajaran Pada Perguruan Tinggi Raharja”. pada penelitian ini penulis membuat suatu bahwa RhjFox dapat membantu mahasiswa untuk mengeluarkan pendapat, ini dikarenakan mahasiswa bebas mengeluarkan pendapat didalam forum diskusi perkuliahan tersebut. Dengan RhjFox mahasiswa dapat langsung berinteraksi dengan dosen maupun dengan mahasiswa lainnya. RhjFox sebagai media pembelajaran cukup efektif dalam proses belajar mengajar. RhjFox di Perguruan Tinggi Raharja akan dapat mendukung proses pembelajaran yang ada, khusunya metode pembelajaran iLearning yang sudah diterapkan di Perguruan Tinggi Raharja sejak tahun 2009.

7. Penelitian yang dilakukan oleh Dewi Immaniar Desrianti, Lusyani Sunarya, Dwi Fitri Parmania (2015) penelitian ini berjudul "Pemanfaatan Teknologi Informasi dan Komunikasi (TIK) Pada RhjFox Sebagai Forum Diskusi”. pada penelitian ini penulis membuat suatu pemanfaatan Teknologi Informasi dan Komunikasi (TIK) yang dilakukan Perguruan Tinggi Raharja dengan membangun Rhjfox sebagai forum diskusi terbilang cukup bagus, dengan design yang mencirikan Perguruan Tinggi Raharja. Forum ini bisa menjadi wadah yang dapat menampung member dalam mencari informasi, baik tentang Perguruan Tinggi Raharja itu sendiri maupun mengenai hal yang belum diketahui. Dengan adanya forum diskusi online ini diharapkan akan lebih efektif bagi setiap member yang terhambat mengenai permasalahan waktu dan tempat untuk bertemu.

8. Penelitian yang dilakukan oleh S. Baramulali, M. Kalyanasundaram, dari Department of Mathematics, Bharathiar University, Coimbatore, India, pada tahun 2006, penelitian ini berjudul "Bootstrap Lower Confidence Limits For The Process Capability Indices $C_{p}, C_{p k}$ and $C_{p m}$ ”. Penelitian ini penulis membuat Indeks kemampuan yang secara luas digunakan oleh profesional kualitas sebagai perkiraan kemampuan proses. Banyak proses indeks telah diusulkan dan dikembangkan dengan $\mathrm{Cp}$, Cpk dan BPT antara yang paling banyak digunakan. Baru-baru ini, teknik telah dikembangkan untuk membangun batas kepercayaan 95 persen lebih rendah untuk setiap indeks. Teknik ini didasarkan pada asumsi bahwa proses mendasaribiasanya didistribusikan. Metode intensif non-parametric tapi komputer yang disebut Bootstrap dimanfaatkan dan batas keyakinan Bootstrap dihitung untuk indeks ini.Simulasi 
menggunakan tiga distribusi (normal, log-normal dan chi-squared) dilakukan dan perbandingan dibuat pertunjukan Bootstrap dan perkiraan parametrik.

9. Penelitian yang dilakukan oleh B. Pozsgay, G.Takacs, dari Institute for Theoretical Physics, Eötvös University, Budapest, Hungary, 29 Juni 2007, penelitian ini berjudul "Form Factor Bootstrap And Truncated Conformal Space". Penelitian ini penulis membuat tentang mempelajari koreksi terbatas ukuran order terkemuka (Lüscher's $\mu$ istilah) terkait dengan bergerak satu-partikel Serikat, Serikat sewenang-wenang berserakan dan faktor-faktor bentuk terbatas volume $(1+1)$-dimensi model integrable. Metode kami didasarkan pada gagasan bahwa istilah $\mu$ erat terhubung ke struktur batin partikel,yaitu, komposisi mereka di bawah bootstrap program. Kami menggunakan kelanjutan analitik persamaan Bethe-Yang sesuai untuk kuantisasi negara-negara yang terikat dalam volume terbatas dan memperoleh $\mu$-istilah terkemuka (terkait dengan fusions simetris partikel) dengan menghitung penyimpangan dari prediksi kuantisasi Bethe-Yang biasa. Hasil kami dibandingkan dengan data numerik teori hamburan E8 diperoleh dengan pendekatan ruang fermionic yang terpotong. Sebagai produk sampingan yang terlihat bahwa kuantisasi terikat negara tidak hanya menghasilkan $\mu$ istilah yang benar, tetapi juga menyediakan jumlah subset dari koreksi urutan yang lebih tinggi juga.

10. Penelitian yang dilakukan oleh M. Szots, G. Takacs, dari Eötvös University, Budapest, Hungary, 23 April 2007, penelitian ini berjudul "Spectrum Of Local Boundary Operators From Boundary Form Factor Bootstrap”. Penelitian ini penulis membuat tentang menggunakan pola persamaan bootstrap faktor bentuk baru-baru diperkenalkan batas, kita peta ruang lengkap solusi untuk versi skala Lee - Yang model dan sinhGordon teori batas. Kami menunjukkan bahwa ruang lengkap solusi, dinilai oleh perilaku ultraviolet formulir faktor dapat dibawa ke dalam korespondensi dengan spektrum operator lokal batas yang diharapkan dari teori konformal batas lapangan, yang merupakan bukti utama bagi kebenaran batas formulir faktor bootstrap kerangka.

Setelah melakukan tinjauan dari sepuluh literatur review yang ada, telah banyak penelitian mengenai penggunaan bootstrap sebagai media informasi. Oleh karena itu penulis membahas tentang "Penerapan Viewboard RhjFox Menggunakan Bootstrap Sebagai Media Informasi Pada Perguruan Tinggi" untuk mengolah data yang terdapat pada RhjFox menjadi sebuah viewboard yang menampilkan informasi akurat dan terkini yang berkaitan dengan perihal RhjFox.

\section{PEMECAHAN MASALAH}

Untuk menyelesaikan masalah-masalah diatas, maka diperlukan sebuah sistem yang efisien, user-friendly untuk dapat menampilkan data-data atau kesimpulan dari informasi luas yang diberikan oleh basis data RhjFox sendiri. Dalam mencapai tujuan tersebut, diperlukan metode analisa yang nyata berupa viewboard RhjFox. 


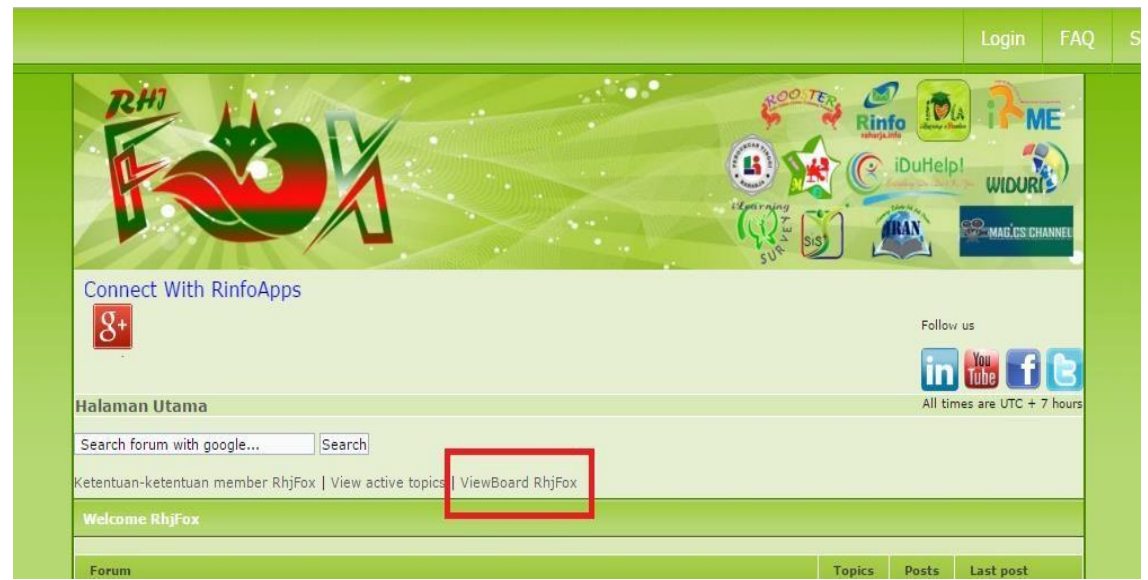

Sumber : http://rhifox.com/

Gambar 3. Tampilan RhjFox Dengan Viewboard RhjFox

Dari rumusan masalah tersebut dapat disimpulkan bahwa tanpa adanya viewboard RhjFox tidak bisa dengan mudah mengetahui data-data yang ada di RhjFox. Pada pemecahan masalah ini viewboard RhjFox menggunakan mind mapping seperti dibawah ini.

\section{Mind Mapping}

Mind Mapping adalah cara paling efektif dan efisien untuk memasukan, menyimpan dan mengeluarkan data dari atau ke otak. Sistem ini bekerja sesuai cara kerja alami otak kita, sehingga dapat mengoptimalkan seluruh potensi dan kapasitas otak manusia ([Menurut Caroline Edward 2009:64]).

Metode Mind Mapping adalah cara kreatif bagi peserta didik secara individual untuk menghasilkan ide-ide, mencatat pelajaran atau merencanakan penelitian baru ([Menurut Melvin L. Silberman 2005:177]). Pada metode Mind Mapping viewboard RhjFox ini menjelaskan mengenai viewboard RhjFox yang ada pada Perguruan Tinggi Raharja, yaitu dengan pengertian viewboard RhjFox, suatu sistem informasi yang melengkapi forum RhjFox yang fungsinya untuk menampilkan aktivitas serta tolak ukur di dalam forum RhjFox ataupun untuk mengetahui informasi terbaru dari forum RhjFox sistem viewboard ini berbasis bootstrap.

Tampilan viewboard RhjFox yaitu terdapat tampilan 10 menu, terdapat tampilan about viewboard, terdapat tampilan contact viewboard, terdapat tampilan location, terdapat tampilan sosial media RhjFox, dan terdapat tampilan visitors. kelebihan viewboard RhjFox yaitu sebuah sistem viewboard yang merekapitulasi seluruh aktifitas dalam forum diskusi RhjFox milik Perfuruan Tinggi Raharja, dengan adanya viewboard, maka data-data mentah yang ada pada basis data RhjFox dapat ditampilkan dengan dinamis dan menarik, juga diharapkan bermanfaat bagi civitas akademik Perguruan Tinggi Raharja. Kekurangan viewboard RhjFox yaitu tampilannya yang masih kaku dan belum menjadi user-friendly, serta rekapitulasi data yang ditampilkan masih belum banyak, juga filterisasi datanya masih terlalu luas ketika masuk ke dalam detail sebuah pilihan data yang disajikan. 


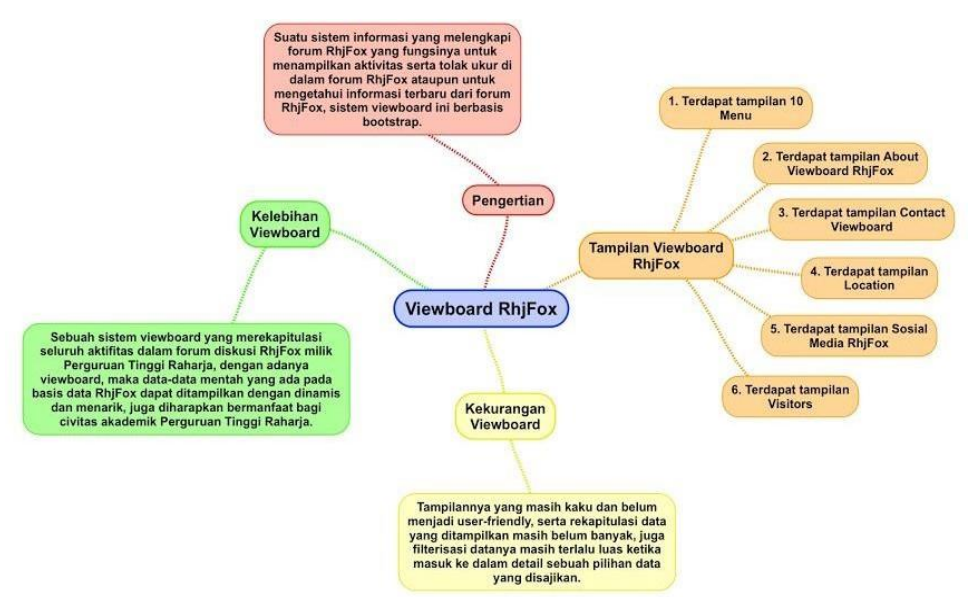

Gambar 4. Mind Mapping Viewboard RhjFox

\section{Strategi}

Langkah-langkah yang tertuang didalam strategi project yang merupakan sebuah proses pencapaian guna meningkatkan viewboard RhjFox agar menjadi lebih optimal serta lebih baik lagi untuk digunakan oleh Pribadi Raharja, dan telah dibuatkan 15 strategi seperti yang ada pada gambar dibawah ini :

\section{Tabel 1. Eliminasi dari hasil elisitasi 15 Strategi yang dilakukan} pada Viewboard RhjFox

\begin{tabular}{|c|c|c|}
\hline No & Strategy & Status \\
\hline 1. & Menampillkan Subscriber di Viewboard RhiFox dengan 250 Subscriber & $\checkmark$ \\
\hline 2. & Memasang Widget di Halaman Viewboard dengan di comment 10 orang & $\checkmark$ \\
\hline 3. & Mengganti Subdomain Viewboard "noval" menjadi "ViewboardRhjF ox' & $\checkmark$ \\
\hline 4. & $\begin{array}{l}\text { Menampilkan Favicon pada Viewboard RhjF ox Dengan di Comment } \\
\text { Oleh } 10 \text { Orang }\end{array}$ & $\checkmark$ \\
\hline 5. & $\begin{array}{l}\text { Menampilkan Menu FAQ pada Vietwboard RhyF ox Dengan di Comment } \\
\text { Sebanyalk } 10 \text { Orang }\end{array}$ & $\checkmark$ \\
\hline 6. & Mengganti Contact Me di Viewboard RhyFox & $\checkmark$ \\
\hline 7. & Membuat Buku Saku RhjF ox Dengan di comment 10 Orang & $\checkmark$ \\
\hline 8. & Menambahkan 1 Menu Dalam Viewboard RhyFox & $\checkmark$ \\
\hline 9. & $\begin{array}{l}\text { Menampillkan Visitor Pada Viewboard RhjF ox Dengan di Comment } 15 \\
\text { Orang }\end{array}$ & $\checkmark$ \\
\hline 10. & $\begin{array}{l}\text { Memasulkkan Artikel FAQ ke dalam Viewboard RhyFox Dengan di } \\
\text { Comment } 10 \text { Orang }\end{array}$ & $\checkmark$ \\
\hline 11. & Membuat Video RhjF ox Sebanyak 5 Video & $\checkmark$ \\
\hline 12. & $\begin{array}{l}\text { Memasulkkan Video RhyFor Kedalam Magics Chamnel Dengan di } \\
\text { Comment Sebanyak } 10 \text { Orang }\end{array}$ & $\checkmark$ \\
\hline 13. & Menambahkan Buku Saku Kedalam Viewboard RhjFox & $\checkmark$ \\
\hline 14. & Mengganti Location di Viewboard RhjFox & $\checkmark$ \\
\hline 15. & Mengupdate 5 Video Tutorial di iRan & $\checkmark$ \\
\hline
\end{tabular}

\section{Flowchart Rangcangan Aplikasi}

Bagan alir (flowchart) adalah bagan(chart) yang menunjukkan alir (flow) di dalam program atau prosedur sistem secara logika ([Menurut Jogianto Hartono 2005:795]). Bagan alir program (program flowchart)merupakan bagan alir yang mirip dengan bagan alir sistem, yaitu untuk menggambarkan prosedur di dalam sistem ([Menurut Jogianto Hartono 2005:802]). System flowchart dapat didefinisikan sebagai bagan yang menunjukkan arus pekerjaan secara keseluruhan dari sistem. Bagan ini menjelaskan urut-urutan dari prosedur-prosedur yang ada di dalam sistem. 
Bagan alir sistem menunjukkan apa yang dikerjakan di sistem. Berikut ini adalah flowchart yang ada pada viewboard RhjFox sebagai berikut :

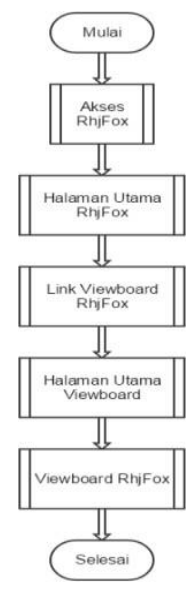

\section{Gambar 5. Flowchart Viewboard RhjFox Yang Sedang Berjalan}

Dapat dijelaskan gambar 5. flowchart program pada ViewBoard RhjFox diatas pada saat ini, yaitu terdiri dari:

1. 2 (dua) simbol terminal, yang berperan sebagai "start" dan "finish" pada aliran proses flowchart program pada sistem ViewBoard RhjFox.

2. 5 (lima) simbol proses yaitu menyatakan suatu tindakan (proses) yang dilakukan oleh komputer. Simbol proses tersebut diantaranya: "akses RhjFox" yang kemudian menuju ke "halaman utama RhjFox" kemudian klik "link ViewBoard RhjFox " yang kemudian akan menuju ke "halaman utama ViewBoard" dan akan tampil data di "ViewBoard RhjFox".

\section{Listing Program}

Di bawah ini adalah kodingan css yang dipakai dalam merancang viewboard RhjFox. Berikut merupakan kodingannya yang berjalan saat ini :

\begin{tabular}{|c|c|}
\hline 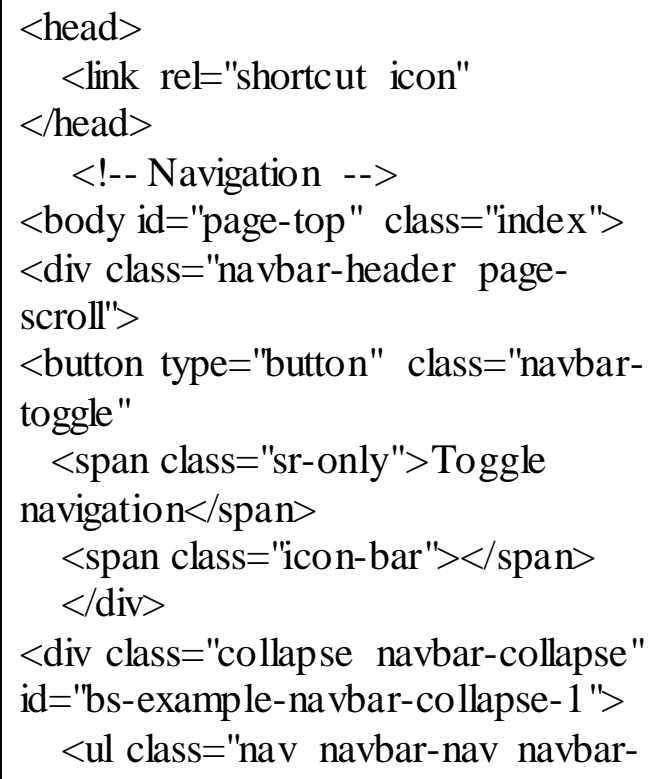 & $\begin{array}{l}?> \\
<\text { html }> \\
<\text { head }></ \text { head }> \\
<\text { body }> \\
<\text { php } \$ \text { no }=1 ; \\
\text { \$sum =0; } \\
\text { \$sql = mysql_query("select username } \\
\text { from fox_users order by user_id desc } \\
\text { limit 1"); } \\
\text { mysql_query (\$query); } \\
\text { while(\$data = } \\
\text { mysql_fetch_array }(\$ s q l)) \\
\{ \\
\text { ? }> \\
\text { "<font color="red" }><b><? \text { php echo } \\
\text { \$data['username'];? }></ b></ \text { font }>"\end{array}$ \\
\hline
\end{tabular}




\begin{tabular}{|c|c|}
\hline 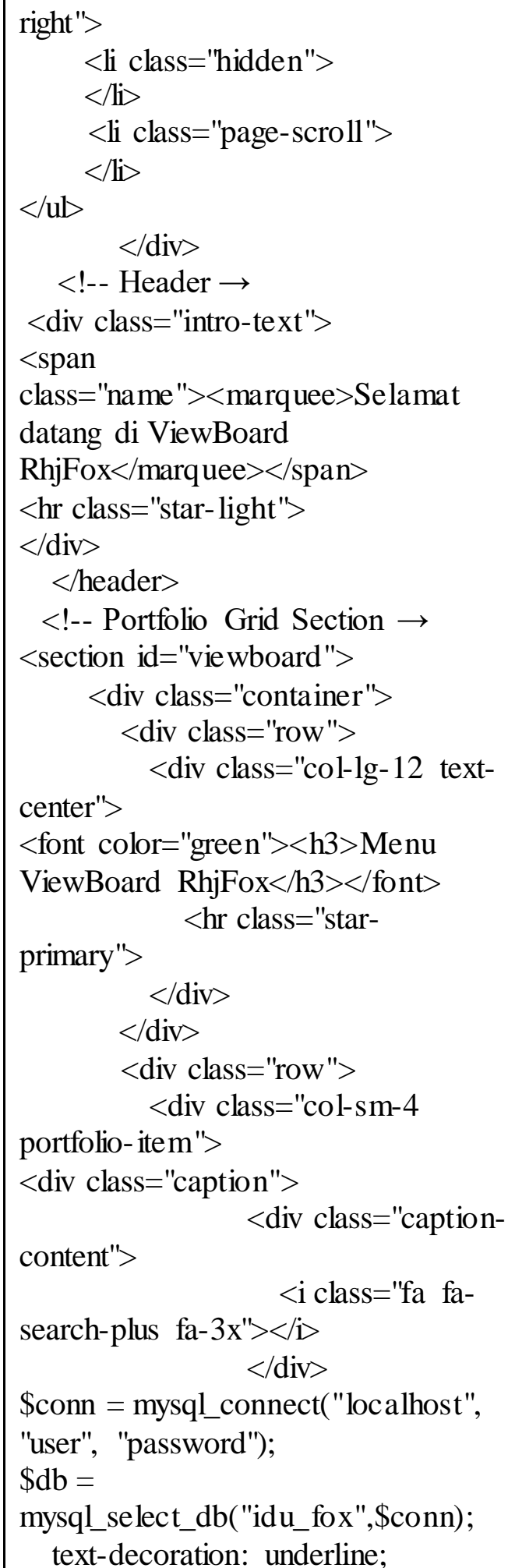 & 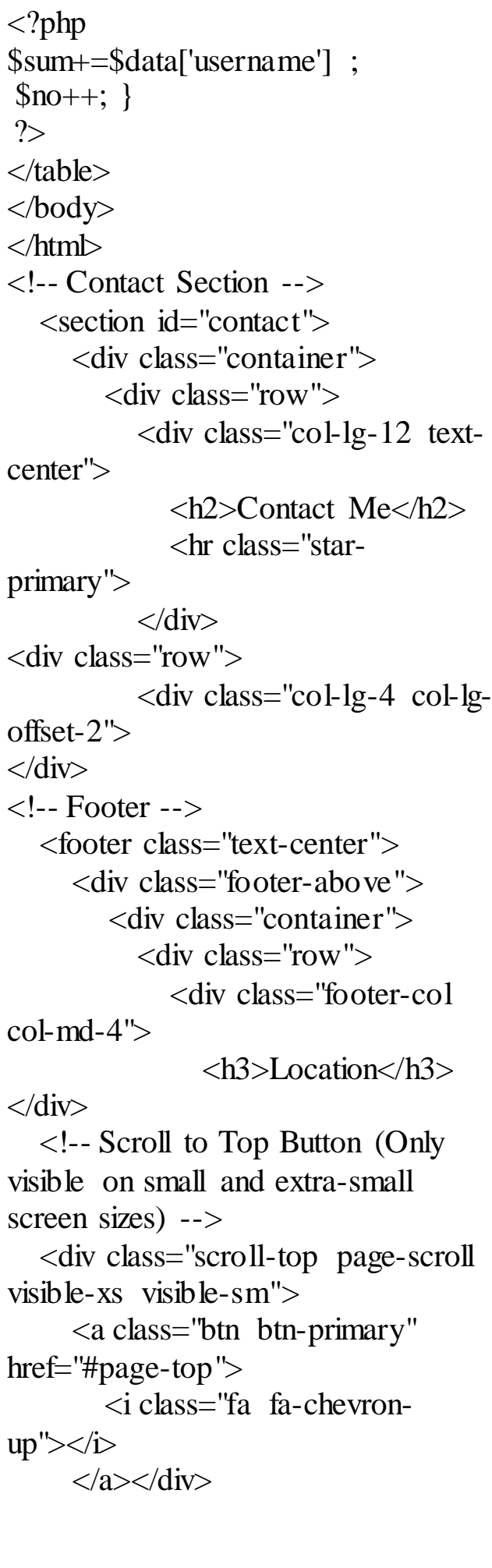 \\
\hline
\end{tabular}

\section{IMPLEMENTASI}

Tampilan sistem viewboard RhjFox memiliki banyak menu penyediaan informasi yang berguna untuk mahasiswa, dosen, atau staf. Antara lain: 


\section{A. Tampilan Utama Viewboard}

Pada tampilan menu utama viewboard ini memberikan pilihan informasi yang diolah dari basis data RhjFox, seperti 10 member terbaru RhjFox, Reply terbanyak pada kategori, daftar member yang menggunakan email Rinfo, dan masih banyak yang lainnya. viewboard RhjFox dapat memberikan beragam informasi lengkap mengenai rekapitulasi statistik RhjFox.

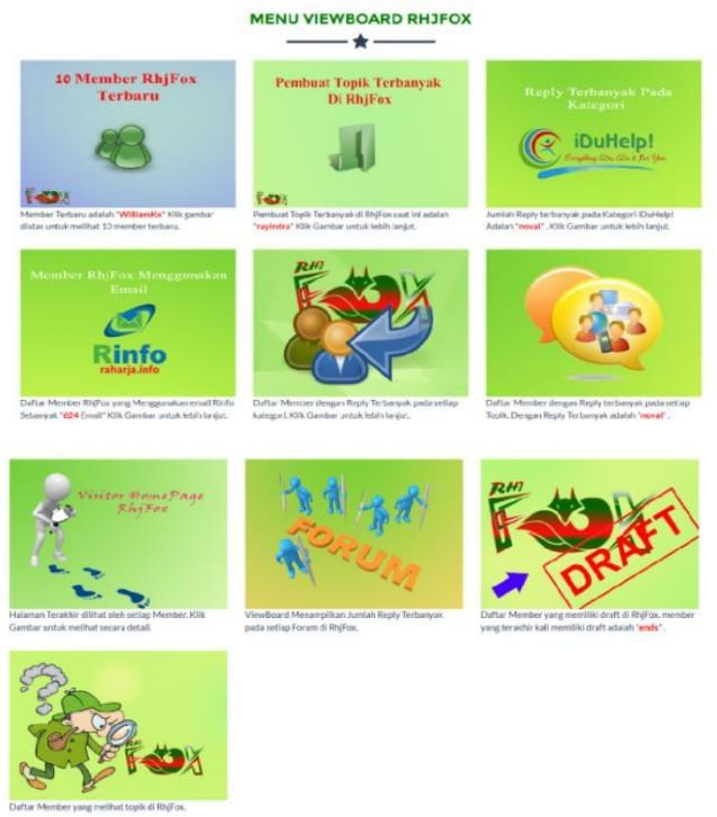

Sumber: http://viewboardrhifox.raharja.infol

Gambar 6. Tampilan Menu Utama Viewboard

\section{B. Tampilan Detail Viewboard}

Tampilan ini menunjukan detail data dari informasi yang dïnginkan oleh pengguna mengenai salah satu menu informasi yang ada.

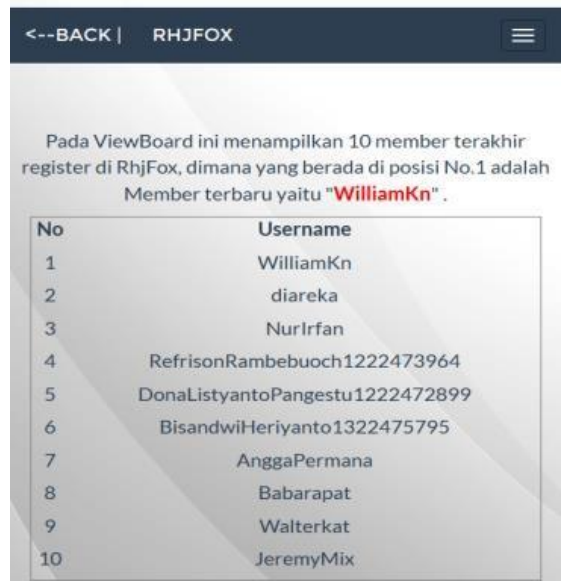

Sumber: http://viewboardrhifox.raharja.infol

Gambar 7. Tampilan Detail 10 Member Terbaru RhjFox 


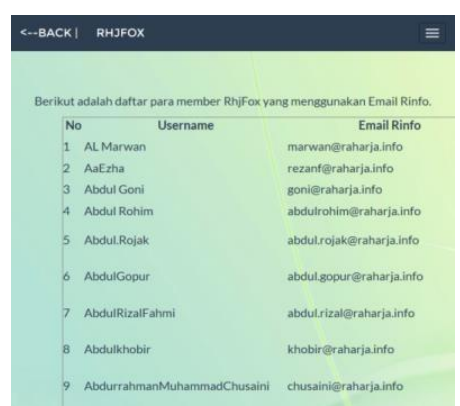

Sumber: http://viewboardrhifox.raharja.infol

Gambar 8. Tampilan Detail Member RhjFox yang menggunakan email Rinfo

C. Tampilan About

Pada tampilan ini hanya menampilkan deskripsi pendek mengenai viewboard RhjFox dan menjelaskan tujuannya.

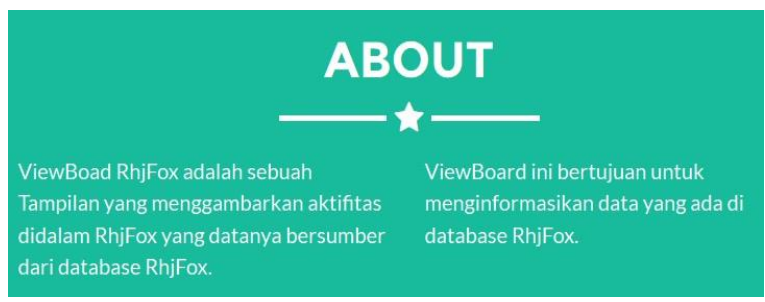

Sumber: http://viewboardrhifox.raharja.infol

Gambar 9. Tampilan About Viewboard RhjFox

D. Tampilan Contact

Pada tampilan ini menampilkan kontak yang bisa dihubungi jika ada sesuatu mengenai viewboard.

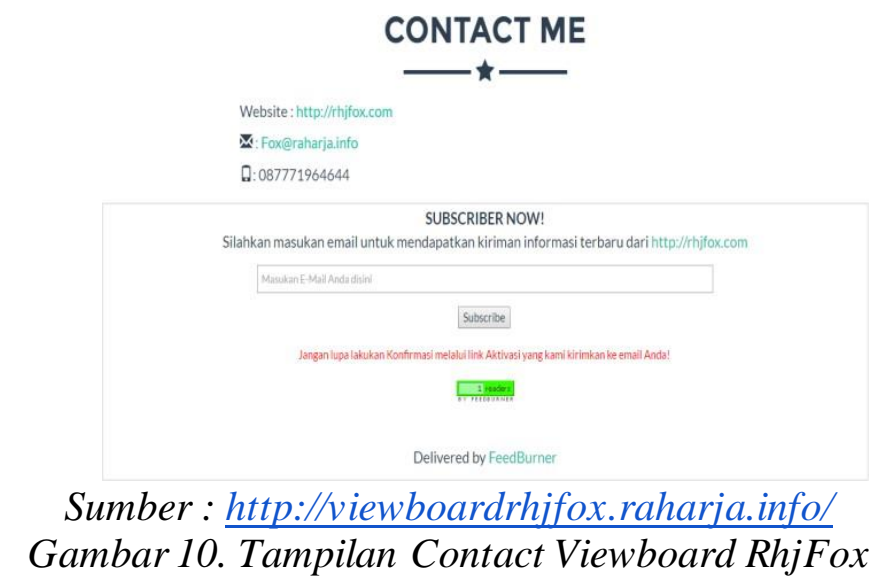

\section{KELEBIHAN}

Dengan adanya penggunaan metode mind mapping dan flowchart dalam menganalisa masalah yang ada, maka dibutuhkan sebuah sistem viewboard yang merekapitulasi seluruh aktifitas dalam forum diskusi RhjFox milik Perguruan Tinggi Raharja. Dengan adanya 
viewboard, maka data-data mentah yang ada pada basis data RhjFox dapat ditampilkan dengan dinamis dan menarik, juga diharapkan bermanfaat bagi civitas akademik Perguruan Tinggi Raharja nantinya.

\section{KEKURANGAN}

Viewboard RhjFox saat ini sudah berjalan dengan baik, tapi bukan tanpa kekurangan. Kekurangan yang terdapat pada viewboard saat ini adalah tampilannya yang masih kaku dan belum menjadi user-friendly. Serta rekapitulasi data yang ditampilkan masih belum banyak. Juga filterisasi datanya masih terlalu luas ketika masuk ke dalam detail sebuah pilihan data yang disajikan. Juga banyak fitur-fitur yang belum ditulis dengan rapih, seperti bagian setelah kontak, bagian alamat dan lain sebagainya.

- Definisi Viewboard : Technology Partners (2014), ViewBoard is a custom application created by Technology Partners, with it you can have the most important information you need to make mission critical business decisions on a daily basis in one easy to read dashboard. From metrics and socials to department level critical information, you decide what you want to have in your custom dashboard. The dashboard interface is fully dynamic, you are able to connect it to a CMS system or have it directly access your database to manage the information feeds.

Dari definisi tersebut dapat disimpulkan bahwa viewboard adalah aplikasi custom yang dibuat oleh Mitra Teknologi, yang fungsinya agar dapat mengetahui informasi penting dan juga informasi yang dibutuhkan.

- Definisi Bootstrap : Menurut Snig Bhaumik (2015), Bootstrap is a frontend framework for faster and easier web development in the new standard of the mobilefirst philosophy. It uses HTML, CSS, and JavaScript. In August 2010, Twitter released Bootstrap as open source.

Dari definisi diatas dapat disimpulkan bahwa Bootstrap merupakan produk Twitter yang digunakan sebagai frontend framework yang menggunakan HTML, CSS, dan JavaScript sebagai fondasinya.

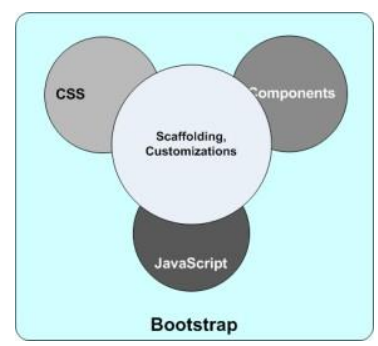

Gambar 11. Struktur Bootstrap

Bootstrap merupakan sebuah framework yang terstruktur atas 3 hal, yaitu CSS, Components, dan JavaScript.

\section{KESIMPULAN}

Dengan demikian dapat penulis simpulkan, bahwa didalam permasalahan ini bagaimana mengolah data yang terdapat pada RhjFox menjadi sebuah viewboard yang menampilkan 
informasi akurat dan terkini yang berkaitan dengan perihal RhjFox, yang nantinya diharapkan dapat menjadi informasi penunjang pengambil keputusan untuk pihak manajerial, dan kepada khalayak ramai umumnya. Dengan adanya viewboard RhjFox metode yang digunakan dalam viewboard ini adalah bootstrap, yang diharapkan dapat memberikan informasi dan manfaat sesuai dengan kebutuhan mahasiswa dan dosen sebagai civitas akademik Perguruan Tinggi Raharja. Juga dapat memberikan sebuah sistem yang baik dengan dasar mind mapping yang telah dilaksanakan. Dan semoga nantinya, viewboard RhjFox ini dapat memaksimalkan kegiatan belajar mengajar pada Perguruan Tinggi Raharja. Dan yang paling penting ialah viewboard ini dapat menghasilkan data yang akurat dan jelas serta dapat membantu pimpinan dalam mengambil suatu keputusan. Dengan adanya viewboard RhjFox ini, diharapkan pengelolaan forum diskusinya menjadi lebih mudah karena terdapat rekapitulasi yang baik serta dapat membantu jalannya forum diskusi yang damai dan kondusif.

\section{DAFTAR PUSTAKA}

[1] Hermawan. 2009. "Penelitian Bisnis". Jakarta: Grasindo.

[2] Sunarya. Lusyani, Radiyanto, Susanti. Erna. 2013. penelitian ini berjudul "Enriching Company Profile Sebagai Penunjang Media Informasi Dan Promosi Pada Perguruan Tinggi Raharja”. CCIT Journal. Vol.7 No.1 - September 2013. ISSN: 1978 - 8282

[3] Wulandari. Septiana , Kurniasari. Dian, Widiarti. 2014. "Pendugaan Galat Baku Nilai Tengah Menggunakan Metode Resampling Jackknife dan Bootstrap Nonparametric dengan Software R 2.15.0”. Jurnal Gradien. Vol. 10 No. 1 Januari 2014 : 963-966. ISSN: 0216-2393.

[4] Fauzy. Akhmad. 2003. "Interval Selisih Rata-Rata Dengan Metode Bootstrap Persentil”. Statistika FMIPA UII Yogyakarta \& siswa Ph.D Statistika UPM Malaysia. Vol. 6. No. 3, 118 - 70, Desember 2003. ISSN : 1410-8518

[5] Prasetyo.Hendro , Kuntoro , Purnomo. Windhu , Soenarnatalina , Adriani.Merry , Wijanarko. Bambang. 2014. "Penerapan Clustering Bootstrap dengan Metode $K$ Means". Jurnal Biometrika dan Kependudukan, Vol. 3, No. 1 Juli 2014: 43-49.

[6] Ilamsyah, Awaludin. Asep, Nurwendah. 2015. "Implementasi Bootstrap Pada Sistem Informasi Perpustakaan Untuk Meningkatkan Pelayanan Mahasiswa Pada Perguruan Tinggi Raharja”. STMIK STIKOM, Bali.

[7] Rahardja. Untung, Frecilia. Yessi, Jindan. Noval. 2015. penelitian ini berjudul "Penerapan Forum RhjFox Menggunakan Metode PHPBB Sebagai Media Pembelajaran Pada Perguruan Tinggi Raharja”. CCIT Journal. Vol.8 No.3 - Mei 2015. ISSN : $1978-8282$.

[8] Desrianti. Dewi Immaniar, Sunarya. Lusyani, Parmania. Dwi Fitri. 2015. penelitian ini berjudul "Pemanfaatan Teknologi Informasi dan Komunikasi (TIK) Pada RhjFox Sebagai Forum Diskusi”. CCIT Journal. Vol.8 No.3 - Mei 2015. ISSN : 1978 -8282.

[9] Baramulali. S, Kalyanasundaram. K. "Bootstrap Lower Confidence Limits For The Process Capability Indices $C_{p}, C_{p k}$ and $C_{p m}$ ". Department of Mathematics, Bharathiar University, Coimbatore, India, 2006. Vol. 19 ISSN: 8/9, pp.1088 - 1097.

[10] Pozsgay. B, Takacs. G. "Form Factor Bootstrap And Truncated Conformal Space". Institute for Theoretical Physics, Eötvös University, Budapest, Hungary, 29 Juni 2007. 
[11] Szots.M, Takacs.G. "Spectrum Of Local Boundary Operators From Boundary Form Factor Bootstrap”. Eötvös University, Budapest, Hungary, 23 April 2007.

[12] Silberman. Melvin L.: 2005; 177. "Pengertian Metode Pembelajaran Mind Mapping".

[13] Edward. Caroline: 2009; 64. 'Pengertian Metode Pembelajaran Mind Mapping".

[14] Arifianto. Rahmat.'Pengertian Flowchart Dan Jenisnya". Diakses pada 20 November 2014 dari https://rahmatarifianto.wordpress.com/2014/11/20/pengertian-flowchart-danjenis-jenisnya/

[15] Jogiyanto, Hartono. 2005. Analis is dan Desain Sistem Informasi, Edisi III. Yogyakarta: ANDI.

[16] Fairuzabadi. Muhammad. "Analisis Sistem Informasi - Pedoman Membuat Flowchart". Diakses pada 13 Januari 2010 dari. https://fairuzelsaid. wordpress.com/2010/01/13/analisis-sistem-informasi-pedomanmembuat-flowchart/

[17] Partners, Technology. 2014. Complete Organization In One Mobile Dashboard. Diambil dari: www.tppr.com/Pages/Dashboard-Product.aspx. (12 Desember 2015).

[18] Bhaumik, Snig. 2015. Bootstrap Essentials. Birmingham: Packt Publishing Ltd.

[19] Atika. Linda. 2010. penelitian ini berjudul "Sistem Penunjang Keputusan Penilaian Kinerja Pemilihan Dosen Berprestasi Menggunakan Metode AHP". Universitas Bina Darma. Vol.12. No.3.

[20] Chrismianto. Deddy. 2005. Penelitian ini berjudul "Pengembangan Sistem Penunjang Keputusan Berbasis Komputer Untuk Peningkatan Efektifitas Sistem Akurasi Dimensi Pada Proses Pembuatan Badan Kapal”. Jurnal Informatika. Vol 6, No 2 (2005). ISSN: 1411-0105. 